\title{
STUDENTS' PERCEPTION TOWARD TEACHERS' TEACHING STYLES AND THE USE OF LEARNING STRATEGIES IN TEACHING ENGLISH
}

\author{
Alfonsus Lamatokan \\ SMA Negeri 1 Tobelo, Halmahera Utara \\ Email : alfonsustokan09@gmail.com
}

\begin{abstract}
The aim of the study was to find out students' perception toward teachers' teaching styles and the use of learning strategies in teaching English. This study was conducted at SMA Negeri 1 Tobelo in all grades. The instrument used in the data collection was a questionnaire that consists of six indicators where these indicators refer to variables. The data were analyzed using Microsoft Excel and display in pie diagram. The finding indicates that the majority of students at SMA Negeri 1 Tobelo are aware that their teachers' teaching styles and the use of learning strategies gave positive impact in do their learning. Their perception of their teachers' teaching styles and learning strategies which covers attitudes, behavior, interaction, method, teaching material and media during teaching and learning process influenced the success of students in developing English skills. Most students of their conviction stated that their English teachers were responsible for their career as a good teacher. Thus, in doing them job, their awareness to make an effective teaching to support students' success in learning English. Further studies might be conducted using interview to students to gain more information.
\end{abstract}

Keywords: Students' Perception, Teachers teaching styles, Learning Strategies.

\section{INTRODUCTION}

Becoming a real teacher is a choice which is based on full awareness to make that profession as a part of our life. Kolo (200:1) states," A real teacher didn't choose the teaching carrier by accident, nor by, for example, coming across a walk-in interview notice in front of a school or an educational intuition, going in and taking the interview and eventually getting the job straight away". According to Hargreaves and Fullan in Richards (2003:385) "the teacher is the ultimate key to educational change and school improvement". In other words, it is what teachers think and do at the classroom level that eventually determines what learners learn in the classroom.

The teacher contribution to education like as teachers' teaching style and the use of learning strategy is very important to support students' success in learning process (Mantasiah et all, 2017; 2018; Yusri et all, 2018; Romadloni et all, 2017). In the past few years, attempts to improve the teaching of English have been intensively done by the government. In service training to English teachers, development of contextual of teaching and learning, and further study funded by ADB (Asian Development Bank) are examples attempts being made so far. All these attempts 
are originated from poor performance of graduated students. We off course know from our every experience that the majority of senior high school has poor performance in English.

Instead of relying on their preferred teaching style, teachers should understand that one style of instruction may not meet the needs of all students. Students differ in the way they approach the learning process and deal with various learning activities (Callahan, Clark, \& Kellough, 2002). One good way to have teachers consider individual learning differences and recognize the need to modify their own teaching style is to have them learn from the student's perspective. Many research has been devoted to teaching styles and learning strategies in higher education. There is little research, however, concerning senior high school students' perceptions of their teachers' teaching styles and their use of learning strategies. Therefore, based on all description above, the researcher decided to conduct a research in order to find out student's perception to the teachers teaching style and the use of learning strategy in teaching English.

\section{THE CONCEPT OF PERCEPTION}

Teaching is really hard work as it requires many skills, thinking, decision and making. It is like a work of art, not a job which anybody can do. Teachers should bear in mind that learning is not a product or outcome. It fact, it is an active process, which involves evaluating the learning experiences, receiving and constructing knowledge. It is the learners' responsibility to learn. The learners may choose to learn, what they learn, when, and why they learn. As Bulut and Durak (2002:2-3) stated' the learners be encouraged to express their perception overtly, both for themselves and their teachers. Doing so would allow learners to consider why they are participating in certain activities, how these activities help them learn English, and what use they can make of them both for academic purposes and outside of the classroom.

As teachers, we should accept the fact that without learners' participants in teaching and learning activities, there will not be effective and enjoyable teaching. That is very main reason for taking the perception for the learners in the classes into consideration. Thus, students' perception plays as a very important role to support the learning process in classrooms activities. Sekuler, R dan Blake, R. (1990) said that" Perception is what person (student) feel about particular thing both conscious and unconscious, whether visual or auditory and thought that are caused by process going on the brain. In other words, perception is people' opinion about something that they are thought is true. It means that perception refers to someone sense or view toward a certain object.

\section{TEACHERS' TEACHING STYLES}

J.J. Hasibun \& Moedjiono (2010:64) stated that" Teaching styles cover attitude, behavior and actions of teachers in implementing teaching and learning activities. Usman (2010:84) states" Teaching style is teachers' activities in order to make interaction in learning process to overcoming students' boredom. Gregorc (1979) indicated that a teaching style consists of a teacher's personal behaviors and the media used to transmit data to or receive it from the learner. Teaching style refers to educators' behaviors as they teach in 
the classroom (Genc \& Ogan-Bekiroglu, 2004). Educators' personal qualities are considered persistent (Conti, 1989; Shieh, 2005). According to Conti, the overall traits and qualities that a teacher displays in the classroom and that are consistent for various situations can be described as teaching style.

Fischer and Fischer (1979) similarly defined teaching style. They stated that the teaching style of an instructor might persist even when he or she uses several different teaching techniques and methods. How teachers teach is related to how they learn. Research supports the concept that most teachers teach the way they learn\| (StittGoheds, 2001, p. 137). Dunn and Dunn (1979) claimed that teachers' teaching styles correspond to their learning styles. Based on their personal learning experiences, teachers tend to teach students how they themselves learn the best and introduce learning strategies that have benefited their own learning.

\section{RESEARCH METHODE}

This research is descriptive research, because as Gay (1997: 142) states, "It does describe an existing condition: it determines and report the way thing are ". In this research provide the description about students' perception to the teachers' teaching style and the use of strategy in teaching and learning process. The target population of this study is the students at SMA Negeri 1 Tobelo in all grades. The minimal sample size is $10 \%$ for a descriptive research (Gay, 1981). In this research, the sample is $15 \%$ from the total population, because the larger sample will be representative data result. There are 1071 students and 159 students, which proportionally and randomly selected as the sample. Thus, proportionally stratified random sampling technique will be used. In this research, the questionnaire is the data collecting instrument. The instrument of this research is related to students' perception to the teachers' teaching style and the use of learning strategy in teaching English at SMA Negeri 1 Tobelo. the data from questionnaire were transformed into numbers and analyzed using Microsoft Excel. The researcher basically counted the respondents' responses per item manually then put into the total number of each option of an item, then use the formula of percentage (15\%) to chosen option per number of all samples which is 159 respondents. The findings data are presented in percentage form and displayed in pie diagram.

\section{FINDING AND DISCUSSION}

The purpose of this study is to describe the students' perception in terms of whether they have positive or negative perception toward their teachers' teaching styles and the use of learning strategies in teaching English or not. According to the findings, majority of students at SMA Negeri 1 Tobelo, have positive responses regarding their teachers' teaching styles and how teachers use learning strategies in teaching and learning process. From the perspective ones focusing on teachers' teaching styles there are three indicators which contains of thirty items questionnaire. The first one was about "Attitude". Based on the data findings most of students gave their perception toward their teachers' attitude in teaching English was very good, it means that they still have satisfied with their teachers in applying his/her attitude teaching. From the total respondents of 159 students in answering ten items questionnaire in 
terms of Teachers Attitude (1285 or $81 \%$ very high) and only (305 or 19\%) lack. They believe that the attitude of their teachers in teaching English was proper and make them comfortable in learning English. These things were clearly enough because the responses of every questionnaire always positively. Even though there are some questionnaires especially question no.2, 4,5, which direct asking about teachers' patience in holding emotion, but responses constant gave positive perception. Thus, it can be concluded that teachers have successfully in applying teaching style in terms of their attitude in learning process.

The second indicator was about teachers' behavior. In this indicator, all questionnaire refers to teachers' characters, awareness, responsibility and habitual action in every learning process. It covers how teachers respect all students, how teachers fair, how teachers as a model to the students. The data findings show that most students tend their perception toward teachers' behavior in teaching English was very good. It proven with the scores that they gave was very high (1311 or $82 \%)$. And only (279 or $18 \%$ ) less. The data result show that students with their consistent gave opinion positively toward teachers' behavior. Thus, it can be concluded that teachers have successfully in applying their good behavior in learning process.

The last indicator was about teachers' interaction. Teachers interaction became important point in learning process because not only students which get the advantages but teachers also get feedback whether teaching material was accepted by the students well. Therefore, teachers should listen students experienced and share with them plays as a very important role to applicated teaching method before coming to the class. Based on the findings show that mostly students have positive responses toward their teachers' interaction. 159 respondents stated their responses of teen questionnaire is very high (1253 or $79 \%$ ) and only 337 or $21 \%$ less. Thus, it can be concluded that teachers really aware of doing interpersonal relationship with students in making good interaction.

The other perspective was about the use of learning strategies in teaching English. In this variable, there were three indicators which consists of thirty items questionnaire. The indicators refer to teachers' Method, subject and Media. First indicator told about method that teachers used in learning process. Teaching method is an act of teachers to transform knowledge. Method must be suitable with the subject material. Thus, every teacher should know various kinds of method in order to created good teaching. In this indicator, all questionnaire aimed to how teachers used method in teaching English. From the total sampling of 159 respondents, gave their perception refer to the teachers use method was satisfied. As seen in table 3, most students stated their perception strongly agree (1.338 or $84 \%)$ and (252 or $16 \%)$ sated less. Refer to the data result, it can be concluded that students felt satisfied by the teachers' method in learning process.

The second indicator refer to the subject or teaching material that teachers gave. Teaching material is one of the important aspect to support success in learning process. Whether teachers supplied suitable reference or not. The content of subject must be referred to students need. In this part, all questions aimed to ask 


\section{Eralingua: Jurnal Pendidikan Bahasa Asing dan Sastra Vol.2, No.2, August 2018}

about how teachers design teaching material became unique based on students need. And the data result show that form the total respondents of 159 students gave their perception positively.

The last indicator told about media that teachers used in teaching and learning process. Teen questionnaire covers about how teachers used media or other equipment tools to support students' success in learning English. Question no.1 refers to how teachers' used media in teaching English. And majority have positive perception refer to that question. In question no. 29 , asking about how teachers used variation of media, most respondents gave their perception very good. As seen in table 3,159 of total respondents stated positively (1.150 or $72 \%$ ) and (440 or 28\%) Less. Based on the data result per each indicators of teaching styles, it can be concluded that the scores of positive is 3.840 or $81 \%$. Thus, the majority of the respondents positively agree with the teachers teaching styles to them, while the scores 921 indicates that only $19 \%$ of the respondents were satisfied with their teachers' teaching styles. The same result was appeared in learning strategies where most of respondents positively agree with the use of learning strategies by the teachers in teaching English. They gave scores 3.706 or $81 \%$ while the scores 921 indicates that only $19 \%$ of the respondents were satisfied with their teachers' use learning strategies.

\section{CONCLUSION}

The conclusion on the perception of teachers' teaching styles and the use of learning strategies that can be drawn from the findings and discussion: 1) the majority of students at SMA Negeri 1 Tobelo are aware that their teachers' teaching styles and the use of learning strategies gave positive impact. Their perception of their teachers' teaching styles and learning strategies which cover attitude, behavior, interaction, method, teaching materials and media during teaching and learning process influenced to the success of students in developing English skills. 2) most students with their conviction stated that their English teachers was responsible for his/her career as a teacher. Thus, in doing his/her job has awareness to make effective teaching to support students' success in learning English.

Based on the results and conclusions of the study, the following recommendations were made: 1) the present study should be replicated with senior high school students in tobelo's. It would be beneficial to have other data that could be compared with the results of this study. 2) the research only looked at one school. A study should be conducted using a larger population of senior high school students in Tobelo. This would help identify the similarities and differences of students' perception toward their teachers' teaching styles and the use of learning. Furthermore, the larger sample size, give better chance to have different perspectives of teachers' teaching styles, and their use of strategies. 3) due to the short time frame, this study collected data only using questionnaire. Further studies might be conducted using interviews to students to gain more information.

\section{REFERENCES}

Bulut, T \& Durak, S. (2002). The Difference between the perceptions of ESL Classroom teaching/learning activities in a South African context. Teso Quarterly, 32 (1), 82-105 
Callahan, J. F., Clark, L. H., \& Kellough, R. D. (2002). Teaching in the middle and secondary schools (7th Ed.). Upper Saddle River, NJ: Merrill Prentice Hall.

Gay, L.R. (1981). Educational Research: Competencies for analysis and Aplication. Colombus Ohio:Charles E.Merill Publishing Company.

Gregorc, A. F. (1979). Learning/teaching styles: Potent forces behind them. Educational Leadership, 36(4), 234236.

J.J. Hasibuan \& Moedjiono, (2010). Proses Belajar Mengajar. Bandung: PT. Remaja Rosdakarya.

Kolo, Clemens. (2005). Portrait of Effective English Foreign Language Teachers. Unpublished Dissertation. Malang : Universitas Negeri Malang.

Mantasiah, R. (2018, June). Pay It Forward Model in Foreign Language Learning to Increase Student's Self Efficacy and Academic Motivation. In Journal of Physics: Conference Series (Vol. 1028, No. 1, p. 012178). IOP Publishing.
Mantasiah, R., Juffri, J., \& Yusri, Y. (2017). Keefektifan Model Pembelajaran Jaring Laba-Laba (Webbed) dalam Keterampilan Menulis Karangan Sederhana Bahasa Jerman. Indonesian Journal of Educational Studies, 20(2).

Romadloni, A., \& Mantasiah, R. Intercultural approach in foreign language learning to improve students' motivation. Senior Editors, 6.

Sekuler, R dan Blake, R. (1990). Perception, $2^{\text {nd }}$ Edition. Edited by: R. Blake. New York: McGraw-Hill Education.

Usman, Moh. Uzer. (2009). Menjadi Guru Profesional. Bandung: PT Remaja Rosdakarya.

Wina Sanjaya. (2008). Pembelajaran dalam Implementasi Kurikulum Berbasis Kompetensi. Jakarta: Kencana

Yusri, Y., Mantasiah, R., \& Jufri, J. (2018). The Use Of Two Stay Two Stray Model in English Teaching to Increase Student's Learning Outcome. Journal of Advanced English Studies, 1(1), 39-43. 